\title{
LAYANAN INFORMASI TENTANG PERGAULAN REMAJA DI SMA DAN MA KABUPATEN BENGKAYANG
}

\author{
Novi Andriati ${ }^{1}$, Tri Mega $\mathbf{R}^{2}$ \\ ${ }^{1,2}$ Program Studi Bimbingan dan Konseling Fakultas Ilmu Pendidikan dan Pengetahuan Sosial \\ IKIP-PGRI Pontianak, Jalan Ampera No. 88 \\ 'e_mail: novieandriaty@yahoo.co.id
}

\begin{abstract}
Abstrak
Tujuan dari pengabdian ini adalah:1) Membekali individu dengan berbagi pengetahuan dan pemahaman tentang berbagai hal yang berguna untuk mengenal diri, 2) Merencanakan, dan mengembangkan pola kehidupan sebagai pelajar, 3) Memfasilitasi dan menstimulasi perkembangan siswa, terutama dalam pergaulan dengan orang lain, 5) Mengatasi hambatan perkembangan siswa pada setiap aspek perkembangan, 6) Menuntaskan ketercapaian tugas perkembangan. Metode yang digunakan dalam pemberian layanan informasi menggunakan media audio visual dan penampilan kisah nyata alumni SMA yang terjebak dalam pergaulan bebas (narkoba). Upaya pemanfaatan narasumber memiliki keunggulan tersendiri, yakni informasi yang diberikan cenderung bersifat nyata, berdasarkan hasil pengalamannya. Hasil kegiatan adalah: 1) Seluruh siswa mampu memahami materi yang diberikan dalam layanan informasi, 2) Seluruh siswa secara antusias dalam mengikuti workshop, kondisi ini dapat dilihat dari ketepatan waktu kehadiran hingga selesai kegiatan, dan banyaknya peserta yang bertanya, 3) Masing-masing kelompok aktif dalam memberikan saran pada saat memberikan kesimpulan diakhir kegiatan.
\end{abstract}

Kata Kunci: Layanan Informasi, Pergaulan Remaja, SMA dan MA Bengkayang

\begin{abstract}
The aims of this dedication are: 1) preparing individuals by sharing the knowledge and understanding about the various things that important to know themselves, 2) Planning and developing the patterns of life as a student, 3) Facilitating and stimulating the students' progressing, especially in association with others, 5) Resolving the in each phase of students' progress, 6) Completing the achievement in the progressing task. The method that used in giving the information service are audio visual media and the truth appearance of the high school alumni who are caught up in promiscuity (drugs). The effort resources utilization has its own advantages such as, the information provided is tends to be real, based on the results of their experience. The results of the activity are: 1) All the students were able to understand the material that was provided in information service, 2) All students enthusiastically attended the workshop whichcan be seen from the promptness in attendance until the end of the activity, and the number of the participants who gave the questions, 3) Each groups were active in giving advice when giving conclusion at the end of the activity.
\end{abstract}

Keyword: The information service, teenage association, SMA and MA Bengkayang. 


\section{PENDAHULUAN}

Layanan informasi yaitu: layanan Bimbingan dan Konseling yang memungkinkan peserta didik (klien) menerima dan memahami berbagai informasi (seperti informasi pendidikan dan informasi jabatan) yang dapat digunakan sebagai bahan pertimbangan dan pengambilan keputusan untuk kepentingan peserta didik (klien). Klien tidak hanya peserta didik tetapi bisa juga orang tua atau wali. Layanan informasi, secara umum sama dengan layanan orientasi bermaksud untuk memberikan pemahaman kepada individu-individu yang berkepentingan tentang berbagai hal yang diperlukan untuk menjalani suatu tugas atau kegiatan, atau untuk menentukan arah suatu tujuan atau rencana yang dikehendaki. Layanan orientasi dan informasi merupakan perwujudan dari fungsi pemahaman pelayanan bimbingan dan konseling. Selain itu akan dapat menunjang pelaksanaan fungsi-fungsi bimbingan dan konseling lainnya dalam kaitan antara bahan-bahan orientasi dan informasi itu dengan permasalahan individu (Prayitno, 2010: 260).

Remaja adalah makhluk yang sedang tumbuh dan berkembang untuk menjadi dewasa dikemudian hari, yang diharapkan menjadi investasi bagi orang tua dan masyarakat dan negara di masa mendatang. Remaja harus di dipersiapkan secara benar dan serius dengan cara mengarahkan, membentuk dan mengembangkan potensi intelektual dan kepribadianya melalui rasio, moral dan religius. Harlock (2011: 220) menyatakan bahwa "masa remaja adalah masa transisi perkembangan antara masa kanak-kanak dan dewasa yang pada umumnya dimulai pada usia 12 atau 13 tahun dan berakhir pada usia akhir belasan tahun atau awal dua puluhan tahun". Remaja merupakan persiapan hari ini untuk harapan masa datang. Mereka merupakan tiang umat, bunga bangsa dan tabungan negara. Mereka adalah otot penggerak, (dimana) darah panas yang mengalir dalam tubuh remaja mampu untuk membangkitkan kekuatan. Remaja adalah usia yang dipenuhi dengan semangat yang sangat tinggi tetapi adakalanya semangat tersebut mengarah ke sifat negatif sehinga sering disebut dengan kenakalan remaja. Ada banyak contoh kenakalan remaja terutama sat ini dimana kenakalan remaja tersebut sangat banyak di pengaruhi oleh faktor-faktor eksternal maupun 
internal. Masa remaja merupakan masa krisis identias, dimana remaja mengalami kegoncangan, sehingga pembentukan identias selalu terancam yang biasanya ditandai dengan timbulnya bermacam-macam konflik baru. Remaja adalah masa transisi dari anak-anak ke dewasa. Menghadapi remaja memang bukan pekerjaan mudah. Untuk memahami jiwa remaja dan mencari solusi yang tepat bagi permasalahanya, maka penting bagi kita memahami remaja dan perkembangan psikologinya yaitu konsep diri, intelegensi, emosi, seksual, motif sosial, moral, dan religinya, Kartono (2013: 132).

Permasalahan yang dihadapi ditemukan beberapa kasus pada siswa yang membutuhkan pendampingan disebabkan siswa tersebut sering keluar malam dan tidak pulang kerumahnya selama 1 minggu dan kurangnya Guru Bimbingan dan Konseling di Kabupaten Bengkayang khususnya di SMA/MA, sehingga siswa sulit mendapatkan layanan dalam bimbingan dan konseling untuk meningkatkan pemahamannya dalam bersosialisasi dengan teman sebaya ataupun orang yang lebih tua. Adapun rencana pemecahan masalah yaitu dengan memberikan layanan informasi lanjutan tentang pergaulan remaja, membantu siswa dalam pergaulan yang benar sehingga tugas perkembangannya tidak terhambat dan memberikan saran kepada pihak sekolah agar mengetahui pentingnya keberadaan guru Bimbingan dan Konseling.

Layanan informasi tentang pergaulan remaja merupakan kegiatan layanan yang diberikan guru BK kepada siswa di sekolah. Pemberian layanan ini bertujuan untuk membantu siswa dalam bersosialisasi yang baik dengan lingkungannya dalam setiap aspek pada fase perkembangan siswa. Berikut tujuan dari layanan informasi disekolah: 1) Membekali individu dengan berbagi pengetahuan dan pemahaman tentang berbagai hal yang berguna untuk mengenal diri, 2) Merencanakan, dan mengembagkan pola kehidupan sebagai pelajar, anggota keluarga dan masyarakat, 3) Pemahaman yang diperoleh melalui layanan informasi, digunakan sebagai bahan acuan dalam meningkatkan kegiatan dan prestasi belajar, mengembangkan cita-cita, menyelenggarakan kehidupan seharihari dalam mengambil sebuah keputusan, 4) Memfasilitasi dan menstimulasi perkembangan siswa, terutama dalam pergaulan dengan orang lain, 5) Mengatasi 
hambatan perkembangan siswa pada setiap aspek perkembangan, 6) Menuntaskan ketercapaian tugas perkembangan.

Kajian teori yang berkaitan dengan permasalahan remaja diantaranya: Harlock (2011: 220) menyatakan bahwa "masa remaja adalah masa transisi perkembangan antara masa kanak-kanak dan dewasa yang pada umumnya dimulai pada usia 12 atau 13 tahun dan berakhirpada usia akhir belasan tahun atau awal dua puluhan tahun". Remaja merupakan persiapan hari ini untuk harapan masa datang. Mereka merupakan tiang umat, bunga bangsa dan tabungan negara. Mereka adalah otot penggerak, (dimana) darah panas yang mengalir dalam tubuh remaja mampu untuk membangkitkan kekuatan. Penting bagi usia remaja memiliki rasa nilai-nilai religius yang akan tertanam secara otomatis pada dirinya. Seberapa dalam remaja memahami ajaran-ajaran agama yang telah diajarkan, seorang remaja akan selalu belajar dan memahami sampai ia menemukan ajaran yang benar. Masalah agama pada umumnya diterima seseorang pada masa kecilnya.Semua yang di alami, di terima dan di mengerti sejak kecil akan berkembang dan tumbuh subur, apabila remaja dalam menganut kepercayaan tersebut tidak mendapatkan saran dan kritikan dari pihak di sekelilingnya. Pengalaman yang diperoleh dari masa kecil itu akan menjadi keyakinan sampai masa pertumbuhan remaja ke depan. Kartono (2013: 132) Kenakalan Remaja atau dalam bahasa Inggris dikenal dengan istilah juvenile delinquency merupakan gejala patologis sosial pada remaja yang disebabkan oleh satu bentuk pengabaian sosial. Layanan yang berfungsi untuk mencegah permasalahan tersebut ialah layanan informasi. Layanan informasi adalah layanan Bimbingan dan Konseling yang memungkinkan peserta didik (klien) menerima dan memahami berbagai informasi (seperti informasi pendidikan dan informasi jabatan) yang dapat digunakan sebagai bahan pertimbangan dan pengambilan keputusan untuk kepentingan peserta didik (klien). Klien tidak hanya peserta didik tetapi bisa juga orang tua atau wali. Layanan informasi bertujuan untuk membekali individu dengan berbagi pengetahuan dan pemahaman tentang berbagai hal yang berguna untuk mengenal diri, merencanakan, dan mengembangkan pola kehidupan sebagai pelajar, anggota keluarga dan masyarakat. Pemahaman yang diperoleh melalui 
layanan informasi, digunakan sebagai bahan acuan dalam meningkatkan kegiatan dan prestasi belajar, mengembangkan cita-cita, menyelenggarakan kehidupan sehari-hari dalam mengambil sebuah keputusan (Mungin, E.W, 2010: 34). Sejalan dengan pendapat Winkel (2005: 623) Layanan informasi adalah layanan bimbingan dan konseling yang memungkinkan siswa (klien) menerima dan memahami berbagai informasi seperti informasi pendidikan dan informasi jabatan yang dapat dipergunakan sebagai bahan pertimbangan dan pengambilan keputusan untuk kepentingan siswa.

\section{METODE}

Metode yang digunakan dalam pemberian layanan informasi yaitu menggunakan media audio visual dan penampilan kisah nyata alumni SMA yang terjebak dalam pergaulan bebas (narkoba). Upaya pemanfaatan narasumber memiliki keunggulan tersendiri, yakni informasi yang diberikan cenderung bersifat nyata, berdasarkan hasil pengalamannya. Pelaksanaan kegitan dengan: 1) Merancang jadwal kegiatan, (2) menentukan jenis tempat dan tempat kegiatan, (3) Melakukan koordinasi dengan pihak terkait (pihak internal: angota PPM dan pihak eksternal: Alumni SMA N 1 Kabupaten Bengkayang), (4) Menyusun kerangka kerja dan teknis pelaksanaan, (5) Membagi tugas kerja (job description) masing-masing anggota, (6) Mengumpulkan sumber atau materi sebagai kajian pustaka, dan (7) Merumuskan anggaran yang akan digunakan. Pelaksanaan layanan berbentuk bimbingan klasikal dengan 3 tahapan kegiatan: kegiatan awal, kegiatan inti, dan kegiatan penutup.

Sasaran objek kegiatan ini adalah berbagai literatur kepustakaan yang mendukung pengembangan materi. Peserta PPM mengumpulkan berbagai literatur (buku, jurnal, dan lainnya) yang menunjang dalam merumuskan materi layanan informasi. Literatur yang telah dikumpulkan oleh masing-masing peserta dianalisis dan dipilah untuk dapat digunakan sebagai acuan dalam memeberikan layanan informasi kepada siswa. Sasaran subjek kegiatan adalah siswa SMA Negeri 1 Sungai Raya Kepulauan dan Siswa MA Al- Khairiyah Desa Sungai Bundung, Kabupaten Bengkayang. Alasan dipilihnya Kabupaten Bengkayang 
sebagai tempat kegiatan, dikarenakan daerah tersebut masih banyak siswa khususnya SMA/Sederajat yang belum memahami bimbingan dan konseling. Sasaran hasil yang diharapkan dalam kegiatan ini adalah terlaksananya layanan informasi dalam bentuk satuan layanan yang dapat digunakan oleh siswa SMA/MA dan guru Bimbingan dan Konseling. Berdasarkan keterbatasan waktu dan anggaran maka produk yang akan dihasilkan adalah kumpulan draf materi yang tervalidasi (belum dalam bentuk pencetakan buku).

\section{HASIL DAN PEMBAHASAN}

Kegiatan pemberian layanan informasi tentang pergaulan remaja di SMA N 1 Sungai Raya Kepulauan dan MA Al-Khairiyah Desa Sungai Bundung berjalan dengan lancar. Tidak ditemukan kendala yang secara signifikan mempengaruhi tujuan dari kegiatan. Dari kegiatan tersebut, hasil yang dicapai sebagai berikut: 1) Seluruh siswa mampu memahami materi yang diberikan dalam layanan informasi, 2) Seluruh siswa secara antusias dalam mengikuti workshop, kondisi ini dapat dilihat dari ketepatan waktu kehadiran hingga selesai kegiatan, dan banyaknya peserta yang bertanya, 3) Masing-masing kelompok aktif dalam memberikan saran pada saat memberikan kesimpulan diakhir kegiatan. Kegiatan dilaksanakan dalam bentuk bimbingan klasikal yang dilaksanakan di ruangan kelas XII MA AlKhairiyah dan SMA N 1 Sungai Raya Kepulauan. Siswa yang diberikan layanan dibagi dalam 3 kelompok dengan tujuan mendapatkan layanan yang efektif bagi siswa terutama tentang topik pergaulan dikalangan remaja. Secara teknis pelaksanaan layanan informasi tentang pergaulan remaja di sekolah mencakup: 1) Kegiatan awal, terdiri dari salam dan doa, absen. 2) Kegiatan inti, terdiri dari penyampaian materi menggunakan laptop dan infokus, pemutaran video dan pemaparan dari alumni yang pernah terjebak dalam pergaulan bebas (narkoba), tanya Jawab. 3) Kegiatan penutup, terdiri dari kesimpulan dari materi yang telah dipaparkan, doa dan salam. 


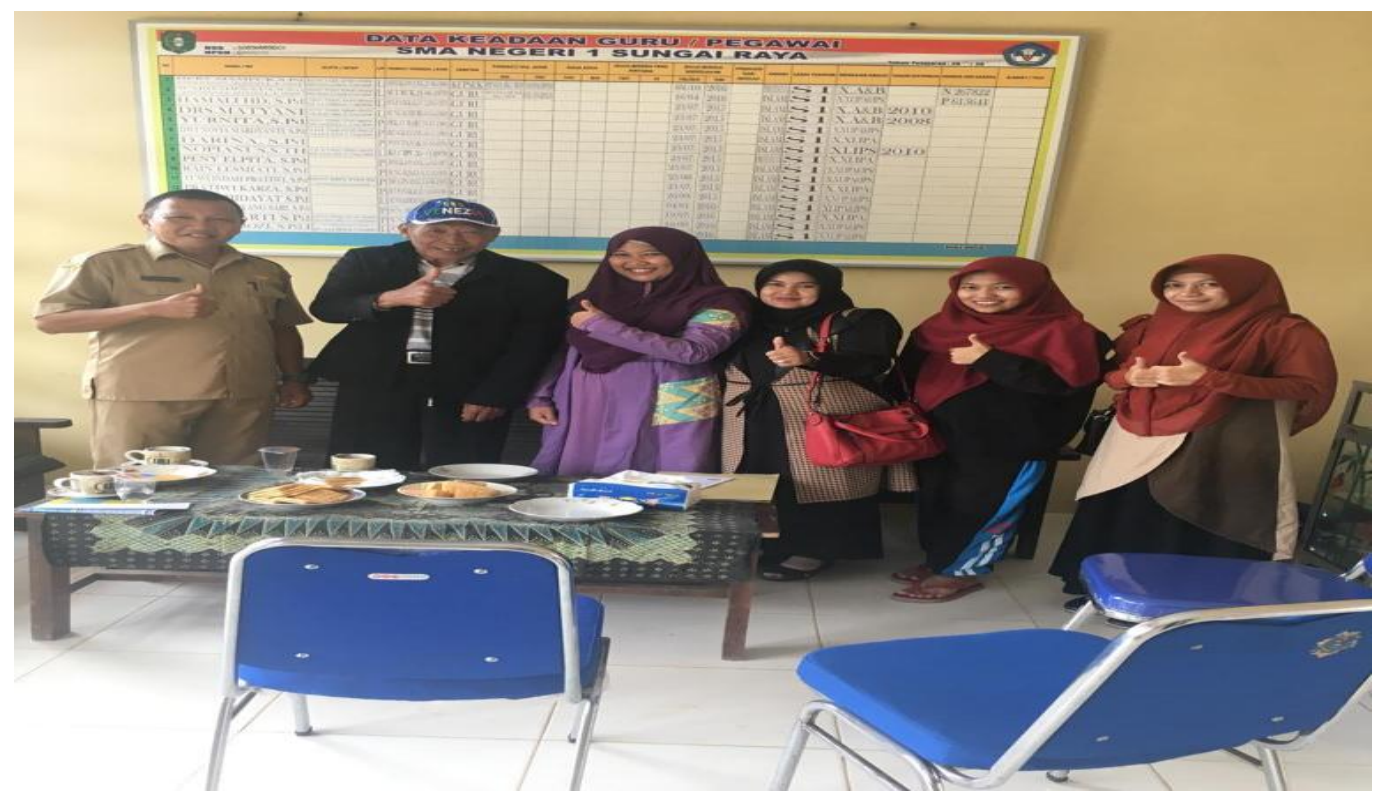

Gambar 1: Anggota Pelaksana PPM

Beberapa kendala yang ditemukan pada saat pelaksanaan layanan informasi diantaranya: 1) Pemberian layanan informasi tentang pergaulan remaja sangat membutuhkan waktu dan konsentrasi yang memadai, sehingga waktu kegiatan 2 hari kurang memadai untuk menyelesaikan permasalahan yang dihadapi siswa, 2) Ditemukan beberapa kasus pada siswa yang membutuhkan pendampingan disebabkan siswa tersebut sering keluar malam dan tidak pulang kerumahnya selama 1 minggu, 3) Kurangnya Guru Bimbingan dan Konseling di Kabupaten Bengkayang khususnya di SMA/MA, sehingga siswa sulit mendapatkan layanan dalam bimbingan dan konseling untuk meningkatkan pemahamannya dalam bersosialisasi dengan teman sebaya ataupun orang yang lebih tua. Solusi mengatasi hambatan yang terjadi: 1) Memberikan layanan informasi lanjutan tentang pergaulan remaja, 2) Membantu siswa dalam pergaulan yang benar sehingga tugas perkembangannya tidak terhambat, 3) Memberikan saran kepada pihak sekolah agar mengetahui pentingnya keberadaan guru Bimbingan dan Konseling. 


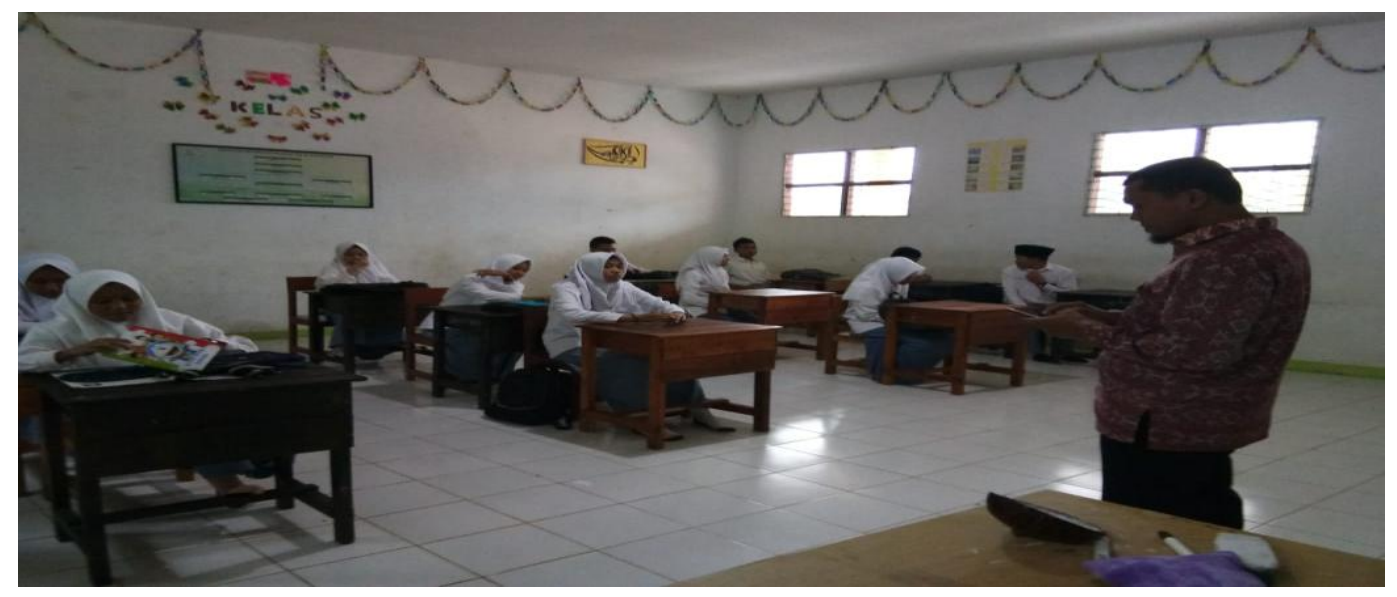

Gambar 2. Pelaksanaan Layanan Informasi

Penelitian yang relevan tentang layanan informasi dan pergaulan remaja: Syamsul , B., Andi, A.A. \& Supiati (2017) dengan judul Pengaruh Layanan Informasi Bidang Bimbingan Sosial Terhadap Perkembangan Perilaku Sosial Siswa. Dari hasil penelitian dapat disimpulkan bahwa ada Pengaruh Layanan Informasi Bidang Bimbingan Sosial Terhadap Perkembangan Perilaku Sosial Peserta Didik Kelas X di SMKNegeri 1 Minasatene, hal ini diketahui dari hasil perhitungan sebelumnya dari Uji Normalitas,Uji Homogenitas dan Uji t-tes. Maka hipotesa yang menyatakan, layanan informasi bimbingan sosial dapat meningkatkan perilaku sosial Peserta didik Kelas X di SMK Negeri 1 Minasatene, dapat diterima. Richma H (2015) dengan judul Layanan Informasi Karir Membantu Peserta Didik dalam Meningkatkan Pemahaman Karir. Hasil penelitian menunjukkan bahwa layanan informasi membantu peserta didik dalam meningkatkan pemahaman karir. Pemahaman yang diperoleh melalui layanan informasi digunakan sebagai bahan acuan dalam mengembangkan cita-cita, menyelenggarakan kehidupan sehari-hari secara efektif dan mengambil keputusan. Layanan informasi ini sangat penting, mengingat bahwa siswa yang menghadapi suatu kesulitan sering membutuhkan informasi tentang lingkungannya. Layanan informasi bertujuan untuk membekali individu dengan berbagai hal yang berguna untuk mengenal diri, merencanakan dan mengembangkan pola kehidupan sebagai pelajar, anggota keluarga, dan masyarakat. Pemahaman yang diperoleh melalui layanan informasi digunakan sebagai bahan acuan dalam meningkatkan kegiatan dan prestasi belajar, 
mengembangkan cita-cita, menyelenggarakan kehidupan sehari-hari dan mengambil suatu keputusan.

Achmad,F (2016) dengan judul Model Bimbingan Konseling Islam Anwar Sutoyo dalam Mengatasi Kenakalan Remaja. Hasil akhir tentang Model Bimbingan KonselingIslam Anwar Sutoyo dalam mengatasi kenakalan remaja dapat penulis simpulkan bahwa model bimbingan dan konseling Islam AnwarSutoyo adalah membantu individu belajar mengembangkan fitrah-iman atau kembali kepada fitrah-iman, dengan cara memberdayakan fitrah (jasmani, rohani, nafs dan iman). Model bimbingan dan konseling IslamAnwar Sutoyo merujuk pada al-Qur'an dan as- Sunnah, menggunakansudut pandang ilmu psikologi dan agama, Bimbingan dan Konseling Islam Anwar Sutoyo menggunakan; bimbingan Qur'ani, Bimbingan individu, bimbingan kelompok. Karakteristik kenakalan remaja menurut Anwar Sutoyo dilihatdari sudut pandang psikologi dan agama. Psikologi menggunakan teori behaviorisme, agama merujuk pada surat an-Nisa' ayat 119. Menurut teori behaviorisme kenakalan remaja itu dikarenakan pengaruh lingkungan, sedangkan pada teori agama dikarenakan faktor pengaruhsetan dan makanan. Bimbingan konseling Anwar Sutoyo dalam mengatasi kenalakan remaja adalah lebih menekankan pada aspek potensi manusia yaitu jasmani, rohani dan iman. Dalam mengatasi permasalahan difokuskan pada mendorong dan membantu individu untuk mempelajari dan mengamalkan agamanya secara benar.Dengan mempelajari dan mengamalkan agama secara benar diharapkan fitrah (iman) yang adapada individu bisa berkembang dengan baik dan selamat dari bujuk rayusetan, dan pada akhirnya diharapkan menjadi hamba yang muttaqin, mutawakkilin, dan mukhlasin.

Yogo, D.P.,Heru. M. \& Ninik. S (2013) dengan judul Hubungan Antara Pelaksanaan Layanan Informasi Bidang Sosial Dengan Kecenderungan Penyimpangan Perilaku Remaja Pada Siswa Kelas Viii Smp Negeri 1 Kaliori TahunAjaran 2012/2013. Hasil dari penelitian ini ialah Pelaksanaan Layanan informasi bidang sosial yang diberikan pada siswa kelas VIII SMP N 1 Kaliori tahun ajaran 2012/2013 termasuk dalam kategori baik dengan rata-rata persentase sebesar 76,34\%. Kecenderungan penyimpangan perilaku yang dilakukan remaja 
pada siswa kelas VIII di SMP N 1 Kaliori tahun ajaran 2012/2013 termasuk dalam kategori tinggi dengan rata-rata persentase sebesar 78,69\%. Terdapat korelasi yang sangat lemah atau dianggap tidak ada hubungan antara pelaksanaan layanan informasi bidang sosial dengan kecenderungan penyimpangan perilaku remaja pada siswa kelas VIII di SMP N 1 Kaliori tahun ajaran 2012/2013, hal ini ditunjukkan dengan perolehan $\mathrm{rxy}=-0.147<\mathrm{rtabel}=0.316$ dengan $\mathrm{N}=32$. Yeni, A., Aziz. M. \& Auliana, F. A (2016) dengan judul Pengaruh Kemandirian Belajar, Pergaulan Teman Sebaya, dan Persepsi Siswa tentang Variasi Guru Mengajar Terhadap Prestasi Belajar Siswa Kelas Xi Ips Mata Pelajaran Ekonomi di MAN Gondanglegi. Hasil penelitian ini ialah: 1) Ada pengaruh yang signifikan secara parsial kemandirian belajar terhadap prestasi belajar siswa kelas XI IPS pada mata pelajaran ekonomi di MAN Gondanglegi, 2) Ada pengaruh yang signifikan secara parsial pergaulan teman sebaya terhadap prestasi belajar siswa kelas XI IPS pada mata pelajaran ekonomi di MAN Gondanglegi, 3) Ada pengaruh yang signifikan secara parsial persepsi siswa tentang terhadap prestasi belajar siswa kelas XI IPS pada mata pelajaran ekonomi di MAN Gondanglegi, 4) Ada pengaruh yang signifikan secara simultan antara kemandirian belajar, pergaulan teman sebaya dan persepsi siswa tentang variasi guru mengajar terhadap prestasi belajar siswa kelas XI IPS pada mata pelajaran ekonomi di MAN Gondanglegi.

\section{SIMPULAN}

Simpulan dari kegiatan PPM adalah kegiatan layanan informasi tentang pergaulan remaja di SMA Negeri 1 Sungai Raya Kepulauan dan MA AlKhairiyah di Kabupaten Bengkayang berjalan dengan lancar. Tidak ditemukan kendala yang secara signifikan mempengaruhi tujuan dari kegiatan. Seluruh siswa mampu memahami materi yang diberikan dalam layanan informasi, dan masingmasing kelompok aktif dalam memberikan saran pada saat memberikan kesimpulan diakhir kegiatan. Hasil yang dicapai yaitu terlaksananya layanan informasi dan pemahaman siswa dalam pergaulannya dengan teman sebaya dan orang yang lebih tua. Diharapkan kepada Pihak sekolah khususnya guru BK agar 
selalu membantu siswa dalam memberikan pemahaman tentang pergaulan yang baik, sehingga tugas perkembangan siswa tersebut tidak terhambat.

\section{UCAPAN TERIMA KASIH}

Terima kasih diucapkan kepada IKIP-PGRI Pontianak atas dana Pengabdian kepada Masyarakat tahun anggaran 2018 yang diberikan, MA Al-Khairiyah dan SMA Negeri 1 Kabupaten Bengkayang yang telah memberi izin untuk melaksanakan kegiatan PPM.

\section{DAFTAR PUSTAKA}

Achmad, F. 2016. Jurnal Bimbingan Konseling Islami (Volume 6, Nomor 2). Kudus: FDKI IAIN Kudus.

Hurlock.2011. Psikologi Perkembangan. Jakarta: Erlangga.

Kartono.2014. Dinamika Perkembangan Anak dan Remaja. Bandung: Rafika Aditama.

Mungin, E.W. 2010.Bimbingan dan Konseling Kelompok. Semarang: Unnes Pers.

Prayitno. 2010. Dasar-Dasar BK. Jakarta: Rineka Cipta.

Richma, H. 2015. Jurnal Konseling Gusjigang (Volume 1, Nomor 1). Kudus: FKIP Universitas Muria Kudus.

Syamsul , B., Andi, A.A. \& Supiati. 2017. Jurnal Konseling Andi Matappa(Volume 1, Nomor 1). Pangkep: STKIP Andi Matappa.

Winkel.2005. Bimbingan Konseling di Institusi Pendidikan. Yogyakarta: Media Abadi.

Yeni, A., Aziz, M. \& Auliana, F. A. 2016.Jurnal Riset Pendidikan Ekonomi (Volume 1, Nomor 1). Malang: Unikama.

Yogo, D.P.S., Heru, M. \& Ninik, S. 2013.Indonesia Journal of Guidance and Counseling: Theory and Application (Volume 2, Nomor 1). Semarang: Unnes. 